\title{
KERAGAAN PERTUMBUHAN DAN REPRODUKSI ABALON Haliotis squamata Reeve (1846) TURUNAN KETIGA
}

\author{
Gusti Ngurah Permana\#, Fitriyah Husnul Khotimah, Bambang Susanto, Ibnu Rusdi, dan Haryanti
}

Balai Besar Riset Budidaya Laut dan Penyuluhan Perikanan

(Naskah diterima: 22 Agustus 2016; Revisi final: 15 September 2017; Disetujui publikasi: 15 September 2017)

\begin{abstract}
ABSTRAK
Pengamatan pertumbuhan dan reproduksi abalon Haliotis squamata dilakukan di hatcheri Balai Besar Riset Budidaya Laut dan Penyuluhan Perikanan (BBRBLPP) Gondol, Bali. Tujuan dari penelitian ini untuk memperoleh informasi tentang keragaan pertumbuhan dan performansi reproduksi abalon turunan ketiga. Induk H. squamata turunan kedua hasil seleksi yang digunakan untuk menghasilkan benih turunan ketiga mempunyai ukuran panjang cangkang 6,5-7,0 cm. Benih dipelihara dalam bak beton berukuran 2,5 $\mathrm{m} \mathrm{x}$ 1,2 $\mathrm{m} \times 1,0 \mathrm{~m}$ yang diberikan feeding plate sebagai substrat penempelan dan dilengkapi dengan sistem aerasi dan sistem air mengalir. Pakan yang diberikan pada awal pemeliharaan adalah diatom jenis Nitzschia sp. dan M elosira sp. yang telah ditumbuhkan terlebih dahulu pada feeding plate sebelum penebaran benih. Benih F-3 dipelihara sampai menjadi calon induk untuk diamati perkembangan reproduksinya. Pengambilan sampel pertumbuhan dilakukan setiap 10 hari. Pengamatan reproduksi dilakukan pada saat abalon mulai tumbuh gonad sampai matang gonad stadia-III. Hasil penelitian menunjukkan bahwa pertumbuhan abalon sangat dipengaruhi ketersediaan pakan pada plate terutama pada hari ke-50. Proporsi jantan-betina abalon F-3 $(3,3: 1)$ meningkat dibandingkan dengan F-0 dari alam $(2,5: 1)$ menunjukkan ketidakseimbangan jumlah individu yang dapat disebabkan oleh tekanan seleksi. Abalon turunan ketiga pada umur 16 bulan mulai matang gonad dan dapat digunakan sebagai induk untuk pemijahan.
\end{abstract}

\section{KATA KUNCl: abalon; seleksi; F-3; pertumbuhan; reproduksi}

ABSTRACT: Reproductive and growth performance of filial-3 abalone, Haliotis squamata Reeve (1846). By: Gusti Ngurah Permana, Fitriyah Husnul Khotimah, Bambang Susanto, Ibnu Rusdi, and Haryanti

Observation on the growth and reproduction development of Haliotis squamata had been undertaken in the hatchery of the Institute for M ariculture Research and Development (IMRAD) Gondol, Bali. The research was aimed to study of the growth and reproduction performance of filial-3 abalone in supporting seed production in hatchery. Larvae were obtained from natural spawning of filial-2 abalone broodstock with the length shell of $6.5-7.0 \mathrm{~cm}$ in the hatchery. Larvae were reared in $2.5 \mathrm{~m} \times 1.2 \mathrm{~m} \times 1.0 \mathrm{~m}$ concrete tank with aeration and water circulation system. Larval samples were taken every 10 days. Larvae were fed with diatom Nitzschia sp. and Melosira sp. Diatom were grown in the feeding plate before the stocking of abalone larvae. Gonadal development of F-3 abalone was observed from the beginning of the study until the mature gonad of stage-III. The result showed that the abalone growth was greatly influenced by the availability of feed in the plate especially at day 50. Abalone F-3 of sixteen months old reached maturity stage earlier compared to the control. The proportion of male-female of F-3 generation (3.3:1) was higher compared to F-0 (2.5:1), indicated the imbalance in the number of individuals that could be caused by selection pressures. These results suggest that sixteen months old abalones could be used as broodstocks for seed production in hatchery.

\section{KEYWORDS: abalone; selection; F-3; growth; reproduction}

\section{PENDAHULUAN}

Abalon turunan ketiga ( $F-3)$ merupakan hasil pemuliaan menggunakan karakter unggul dalam

\footnotetext{
\# Korespondensi: Balai Besar Riset Budidaya Laut dan Penyuluhan Perikanan. JI. Br. Gondol Kec. Gerokgak Kab. Buleleng, Po. Box 140, Singaraja 81155, Bali, Indonesia. Tel. + 6236292278

E-mail: gustipermana@gmail.com
}

pertumbuhan. Prinsip dasar dari seleksi adalah eksploitasi sifat 'additive' dari alela-alela pada semua lokus yang mengontrol sifat terukur untuk memperbaiki suatu populasi (Tave, 1993; Gjedrem, 2005). Abalon F-3 hasil seleksi diharapkan lebih unggul dalam pertumbuhan dan hasilnya lebih baik dibandingkan dengan F-0 yang berasal dari alam. Fekunditas abalon yang tinggi mencapai 5,56 x 106 
telur per induk betina untuk $\mathrm{F}-0 ; 2,17 \times 10^{6}$ untuk F-1 dan 2,87 x $10^{6}$ untuk F-2 (Permana et al., 2013) memungkinkan program seleksi dapat dengan mudah dilaksanakan.

Balai Besar Penelitian dan Pengembangan Budidaya Laut, Gondol telah berhasil memproduksi benih abalon $H$. squamata skala massal di hatcheri dengan perolehan sintasan benih umur dua bulan berkisar $6,3 \% 18,4 \%$ Namun demikian permasalahan utama dalam pengembangan budidaya abalon adalah pertumbuhannya yang lambat (Onitsuka et al., 2004; Arai \& Okumura, 2013). Hasil penelitian sejak tahun 2011 hingga 2013, diketahui adanya peningkatan laju pertumbuhan abalon $\mathrm{F}-2$ dibandingkan dengan abalon F-1. Bobot abalon F-2 pada umur 12 bulan adalah 22,15 $g$ atau $17,93 \%$ lebih tinggi dibanding dengan bobot abalon F-1 tanpa seleksi (Permana et al., 2015).

Berdasarkan hasil penelitian tentang potensi reproduksi abalon F-0 diperoleh bahwa jumlah telur, diameter telur, derajat penetasan (HR), dan derajat pembuahan (FR) berturut-turut adalah 1.025.646 \pm 300.231 butir; $181,25 \pm 0,96 \mu \mathrm{m} ; 42,30 \pm 21,95 \%$; dan 75,42 \pm 9,65\%(Rusdi et al., 2010). Jumlah telur, diameter telur, derajat penetasan (HR), dan derajat pembuahan (FR) dari abalon F-1 berturut-turut sebesar $1.326 .300 \pm 336.432$ butir; $183,67 \pm 2,12 \mu \mathrm{m} ; 61,43$ $\pm 7,86 \%$ dan $84,66 \pm 15,62 \%$ (Rusdi et al., 2010 ) dan jumlah telur, diameter telur, derajat penetasan (HR), dan derajat pembuahan (FR) dari abalon F-2 berturutturut sebesar 7.985.000 \pm 371.749 butir; 186,50 \pm $2,16 \mu \mathrm{m} ; 72,66 \pm 8,74 \%$; dan $91,13 \pm 0,82 \%$ (Rusdi et al., 2015). Informasi tersebut menunjukkan bahwa keragaan reproduksi abalon $\mathrm{H}$. squamata dapat ditingkatkan melalui proses seleksi.

Populasi abalon F-3 yang diperoleh dari induk F-2 hasil seleksi diharapkan juga memiliki keragaan reproduksi dan pertumbuhan yang lebih baik dibandingkan dengan generasi sebelumnya. Untuk itu, penelitian ini dilakukan untuk menentukan performa pertumbuhan dan reproduksi abalon F-3 untuk mendukung produksi benih abalon.

\section{BAHAN DAN METODE}

\section{Pertumbuhan}

Pemeliharaan benih abalon $\mathrm{H}$. squamata dilakukan di multispecies hatchery (MSH) Balai Besar Penelitian dan Pengembangan Budidaya Laut (BBPPBL) Gondol, Bali selama 90 hari. Pemeliharaan larva abalon dilakukan dalam bak beton berukuran 4,2 $\mathrm{m}$ x 2,3 m x 1,2 m. Bak dilengkapi dengan sistem aerasi (kecepatan aerasi 0,4 liter/menit). Dalam bak pemeliharaan Iarva ditempatkan substrat penempelan larva dari bahan plastik fiber bergelombang berukuran $58 \mathrm{~cm} \times 60 \mathrm{~cm}$ yang telah ditumbuhi bentik diatom sebagai pakan larva. Penumbuhan diatom pada rearing platedilakukan dua minggu sebelum penebaran larva abalon. Bak yang telah diisi air dan telah diberikan rearing plate kemudian dipupuk dengan menggunakan pupuk teknis $\mathrm{KNO}_{3}: 50 \mathrm{~g} / \mathrm{m}^{3}, \mathrm{Na}_{2} \mathrm{HPO}_{4} .12 \mathrm{H} 2 \mathrm{O}: 4 \mathrm{~g} / \mathrm{m}^{3}$, Clewat-32 : $5 \mathrm{~g} / \mathrm{m}^{3}, \mathrm{FeCl}_{3}: 2,5 \mathrm{~g} / \mathrm{m}^{3}, \mathrm{Na}_{2}$ EDTA : $5 \mathrm{~g} / \mathrm{m}^{3}$, dan $\mathrm{NaSiO}_{3}$ $: 50 \mathrm{~g} / \mathrm{m}^{3}$. Inokulan diatom yang akan ditebar di bak pemeliharaan terlebih dahulu dikultur dalam bak fiber volume 30 liter selama empat hari, dengan kepadatan awal 800.000-1.200.000 sel/mL. Selanjutnya setiap minggu diberikan pupuk susulan setengah dari dosis awal untuk memacu tumbuhnya diatom lainnya dalam bak pemeliharaan larva abalon.

Larva abalon yang digunakan merupakan turunan ketiga (F-3) dari hasil pembenihan induk F-2. Larva ditebar dalam bak pemeliharaan dengan kepadatan 25-30 ekor veliger/L. Setelah berumur 10 hari dan larva telah kuat menempel pada substrat, pada bak pemeliharaan diterapkan sistem air mengalir dengan debit air 1,5-2 liter/menit. Sumber air yang digunakan adalah air laut yang telah melewati saringan pasir dan ultraviolet (UV). Penyifonan dilakukan setiap hari setelah diterapkan sistem air mengalir untuk menjaga kondisi lingkungan selama pemeliharaan.

Setelah mencapai umur 60 hari, benih abalon diberi pakan makroalga jenis Gracilaria sp. dan Ulva sp. dengan dosis ad libitum (Daume \& Ryan, 2004). Pengamatan pertumbuhan benih abalon dilakukan setiap 10 hari yang meliputi pengukuran panjang dan lebar cangkang dilakukan di bawah mikroskop dengan perbesaran 30 kali. Pengukuran panjang dan lebar cangkang benih abalon dilakukan terhadap 10 ekor contoh yang diambil secara acak.

\section{Reproduksi}

Sebanyak 1.000 ekor benih F-3 (umur empat bulan) diambil secara acak dan dipeliharan sampai berumur delapan bulan. Potensi reproduksi diukur dari 800 individu F-3 dan 247 individu induk abalon alam yang diperoleh dari perairan pantai selatan Kabupaten Negara, Bali. Pengamatan reproduksi induk F-3 dilakukan pada saat abalon mulai tumbuh gonad sampai matang gonad. Pengamatan kematangan gonad dilakukan dengan kriteria berdasarkan parameter visual gonad bulk (VGB) seperti dilaporkan Singhagraiwan $\&$ Doi (1992). Pengamatan perkembangan gonad dilakukan setiap 10 hari dengan pertimbangan mengurangi tingkat stres pada induk. Tingkat kematangan gonad diamati dengan analisis preparat histologi. 


\section{HASIL DAN BAHASAN}

\section{Keragaan Pertumbuhan}

\section{Perkembangan awal benih abalon H. squamata F-3}

Hasil pengamatan perkembangan awal benih yang terlihat dari pertumbuhan panjang dan lebar cangkang benih F-3 abalon $\mathrm{H}$. squamata yang dipelihara selama 90 hari pemeliharaan dapat dilihat pada Gambar 1.

Pertumbuhan panjang dan lebar cangkang benih abalon F-3 mengalami peningkatan selama 90 hari pemeliharaan. Pada awal penebaran veliger sampai hari ke-3 abalon masih bersifat planktonis dan masih memanfaatkan energi yang berasal dari kuning telur (yolk). Setelah hari ke-4 abalon mulai menempel pada feeding plate kemudian memanfaatkan diatom sebagai makanan setelah persediaan egg yolk habis.

Pertumbuhan panjang dan lebar cangkang benih abalon meningkat seiring dengan bertambahnya waktu mengikuti pola regresi linier (Gambar 1). Pada awal penebaran sampai hari ke-30 terlihat pertumbuhan yang semakin meningkat. Hal ini dikarenakan kebutuhan nutrisi benih abalon pada awal penempelan hingga umur 30 sudah tercukupi dari pemanfaatan pakan diatom pada plate. Namun pada hari ke-30-50 terjadi penurunan kecepatan pertumbuhan dikarenakan stok diatom pada plate mulai menipis. Periode ini merupakan periode kritis sehingga kecepatan pertumbuhan abalon terganggu, serta terjadi penurunan sintasan karena kompetisi makanan.
Perlambatan pertumbuhan dan penurunan sintasan pada hari ke-30-50 ini dapat dihindari dengan perbaikan metode penumbuhan pakan sehingga nutrisi tetap tercukupi (Rusdi et al., 2010). Adapun jenis diatom yang tumbuh pada bak/feeding plate terdapat sekitar sembilan jenis yaitu Nitzschia spp., Cocconeis placentala, M elosira nummuloides, Navicula, Amphisolenia bidentata, Amphipora gigantean, Hemiaulus sinensis, Coscinodiscus exentricus, dan Rizosolenia stalterfothii.

Pada hari ke-60 dilakukan pemanenan benih abalon dari plate selanjutnya ditempatkan pada keranjang dengan sistem terapung. Pada masa ini abalon diberikan pakan makro alga berupa Ulva sp. Pergantian pakan dari diatom ke makroalga membutuhkan penyesuaian yang berdampak pada penurunan pertumbuhan mulai dari panen pada hari ke-60 sampai dengan hari ke-70. Setelah masa tersebut pertumbuhan abalon meningkat kembali seperti terlihat pada Gambar 1.

\section{Keragaan Reproduki F-3}

\section{Potensi reproduksi F-3}

Dari 800 individu abalon turunan ketiga yang diambil sebagai sampel, ditemukan sebanyak 614 ekor jantan dan 186 ekor betina, dengan seks rasio jantan: betina (3,3:1). Sementara sebanyak 247 individu abalon dari alam, individu jantan mendominansi sampel berjumlah 177 ekor dan 70 ekor betina. Hal ini menunjukkan bahwa seks rasio jantan dan betina (2,5:1). Hasil ini sesuai dengan Botsford et al. (1997),

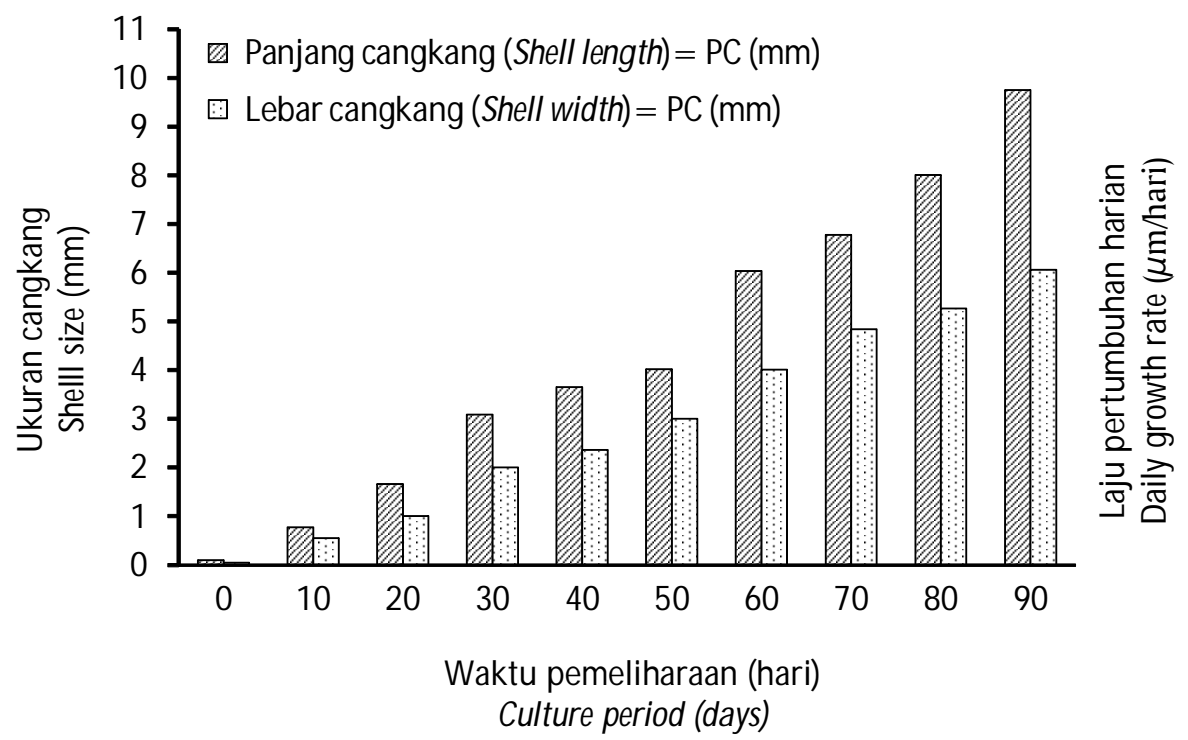

Gambar 1. Keragaan pertumbuhan benih F-3 abalon H. squamata; $\mathrm{PC}=$ panjang cangkang, $\mathrm{LC}=$ lebar cangkang.

Figure 1. Growth performance of seed F-3 abalone $\mathbf{H}$. squamata; $\mathrm{PC}=$ shell length, $\mathrm{LC}=$ shell width. 
yang menyatakan bahwa adaptasi distribusi abalon jantan lebih mampu bertahan terhadap perubahan lingkungan pada daerah yang terbuka. Meningkatnya proporsi jantan pada abalon turunan ketiga menunjukkan ketidakseimbangan jumlah individu yang dapat disebabkan oleh tekanan seleksi. Namun demikian hal yang sangat berdeda dikemukakan oleh Bilbao et al. (2010), yaitu struktur populasi jantanbetina abalon Haliotis tuberculata coccinea di Pulau Canary adalah 1:1,02. Rasio jenis kelamin individuindividu dalam suatu populasi terkait langsung dengan potensi reproduksi dari individu anggota populasi tersebut (Jiaqi et al., 2017).

\section{Tingkat Kematangan Gonad}

Perbedaan tingkat kematangan gonad dapat dipengaruhi oleh beberapa faktor eksternal dan faktor internal, meliputi curah hujan, suhu, sinar matahari, tumbuhan, dan ketersediaan makanan, serta kondisi tubuh dan adanya hormon reproduksi. Perkembangan gonad abalon turunan ketiga terlihat ada peningkatan dengan meningkatnya umur abalon. Tingkat kematangan gonad pada abalon sangat bervariasi, yang mengindikasikan bahwa abalon dapat memijah secara alami sepanjang tahun. Induk abalon umur 16 bulan memiliki persentase kematangan gonad jantan dan betina pada stadia-III masing-masing sebesar $21,0 \%$ dan $18,2 \% \mathrm{Hal}$ ini mengindikasikan bahwa abalon turunan ketiga (F-3) telah mencapai ukuran dewasa dan dapat bereproduksi pertama kali pada umur 18 bulan (Gambar 2). Hal ini sangat berbeda jika dibandingkan dengan abalon, $\mathrm{H}$. asinina yang berasal dari alam mencapai ukuran dewasa dan diperkirakan bereproduksi pertama kali pada berumur 25 bulan (Setyono, 2004).

\section{Histologi Gonad F-3}

Pengamatan histologi gonad dilakukan untuk menentukan stadia dari oosit dan spermatid. Pada gonad stadia-III, jaringan ikat yang menjulur hingga mencapai bagian dalam gonad membentuk lembaranlembaran yang disebut trabekula yang kemudian terhubung dengan kapsula tipis yang membungkus hepatopankreas. Gonad terbagi menjadi bagian-bagian kecil dengan yolk, nukleus, dan noklueolus yang terlihat jelas (Gambar 3A).

Pada fase memijah sebagian (partially spawned) terbentuk rongga ovari dan terdapat bagian dengan ovum yang padat. Bagian yang longgar sebagian ovum yang tidak dikeluarkan tetap terikat pada trabekula. Pada fase ini dibutuhkan beberapa waktu hingga terjadi o genesis dan rongga ovari akan dipenuhi oleh ovum yang matang (Gambar B). Abalon tetap dapat memijahkan telurnya apabila mendapat rangsang baik secara alami maupun buatan.

Gonad jantan diselimuti oleh kapsula yang tersusun dari serabut kolagen yang padat bercampur dengan sel otot. Jaringan ikat yang menjulur hingga mencapai bagian dalam gonad membentuk lembaran-lembaran yang disebut trabekula. Trabekula sebagai tempat melekatnya sel-sel gamet. Sel gamet pada tahap awal
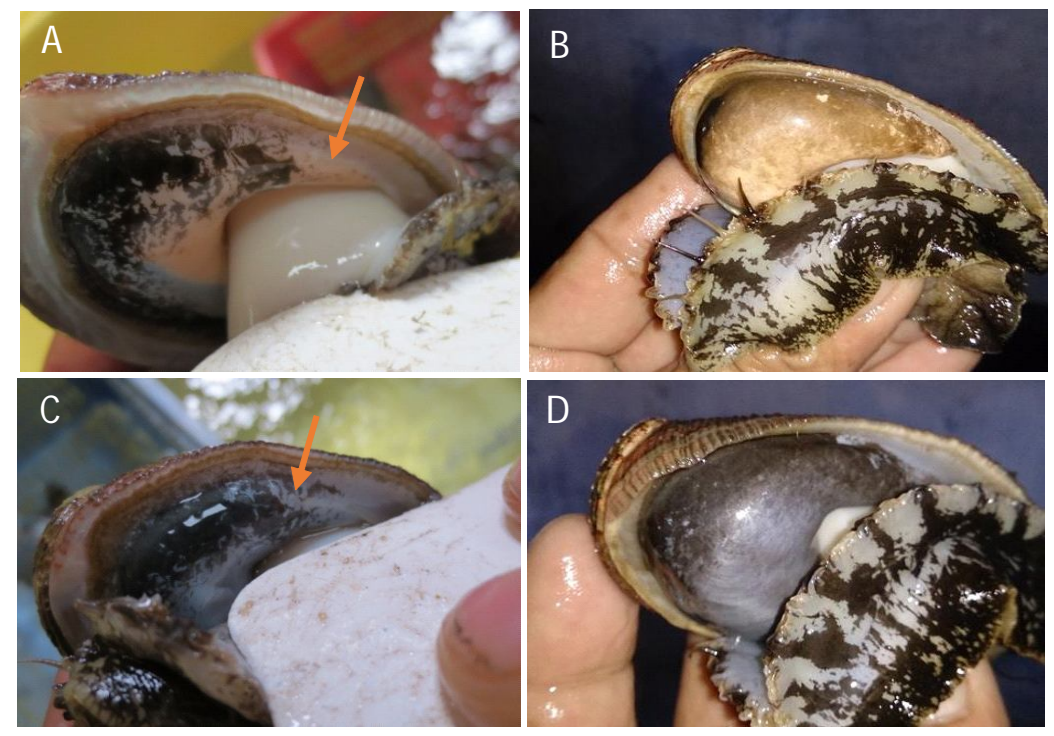

Gambar 2. Tingkat kematangan gonad induk abalon (A). TKG-I pada induk jantan; B). TKG-III pada induk jantan, C). TKG-I pada induk betina, dan D). TKG-III pada induk betina].

Figure 2. Gonadal development stages of abalone spawners $[\mathrm{A}) .1^{\text {st }}$ gonad maturation stage of male abalone; B). $3^{\text {rd }}$ gonad maturation stage of male abalone; C). $1^{\text {st }}$ and D). $3^{\text {rd }}$ gonad maturation stage of female abalone]. 
yaitu spermatogonia dan oogonia dapat terlihat dengan jelas melekat pada trabekula. Perkembangan selanjutnya dari spermatogonia atau oogonia terlihat berada lebih jauh dari trabekula (Gambar 3C), yang kemudian terhubung dengan kapsula tipis yang membungkus hepatopankreas. Pembuluh pembuluh kapiler mengalami percabangan yang terhubung dengan pembuluh yang lebih besar (Apisawetakan et al., 1997). Sperma dan telur dikeluarkan melalui rongga dari organ ginjal yang letaknya di sebelah dorsal dari hepatopankreas dan akan dikeluarkan melalui lubanglubang yang ada pada cangkang.

\section{Diameter Telur, Derajat Pembuahan, Rasio Penetasan, dan Sintasan}

Diameter telur abalon F-3 $(n=50)$ adalah $185,5 \pm$ $1,4 \mu \mathrm{m}$; lebih rendah jika dibandingkan dengan $\mathrm{F}-2$ $(186,5 \pm 2,0 \mu \mathrm{m} ; \mathrm{n}=50)$. Namun demikian, nilai ini secara statistik tidak berbeda nyata $(P>0,05)$. Diameter telur merupakan salah satu indikator dari kualitas telur. Hal yang sama terlihat pada $\mathrm{H}$. asinina dari alam dengan diameter telur mencapai $180 \mu \mathrm{m}$ (Botsford et al., 2006). Derajat pembuahan (fertilization rate) telur $\mathrm{F}_{3}$ mencapai $92,07 \%$ dengan daya tetas mencapai $66,67 \%$

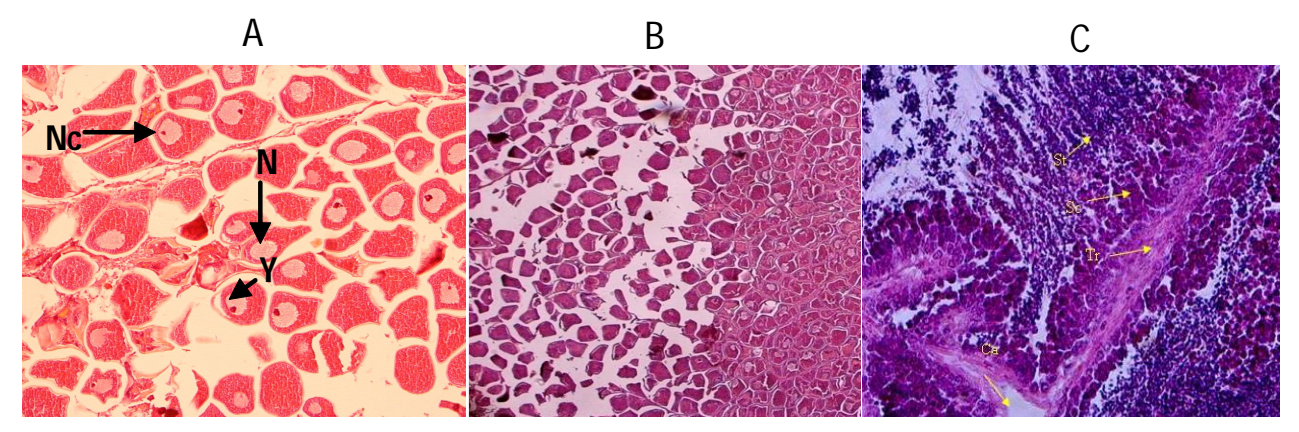

Gambar 3. Histologi gonad stadia III (A) Y: yolk; N: nukleus; Nc: nukleolus (pembesaran 100x); (B) kondisi histologis gonad betina pada stadia memijah sebagian (perbesaran 40x). (C) gonad jantan, $\mathrm{Ca}$ : pembuluh kapiler; Tr: trabekula, jaringan ikat tempat melekatnya spermatogonium; Sc: spermatosit; St: spermatid; Sz: spermatozoa (perbesaran 200x).

Figure 3. Histology of $3^{\text {rd }}$ stage gonad (A) Y: yolk; N: nucleus; Nc: nucleolus; (100x magnification; (B) histology of female gonad after spawn 40x magnification; (C) male gonad, Ca: capllaries; Tr: trabeculae, connective tissue attachment; Sc: spermatocyte; St: spermatid; Sz: spermatozoa (200x magnification).

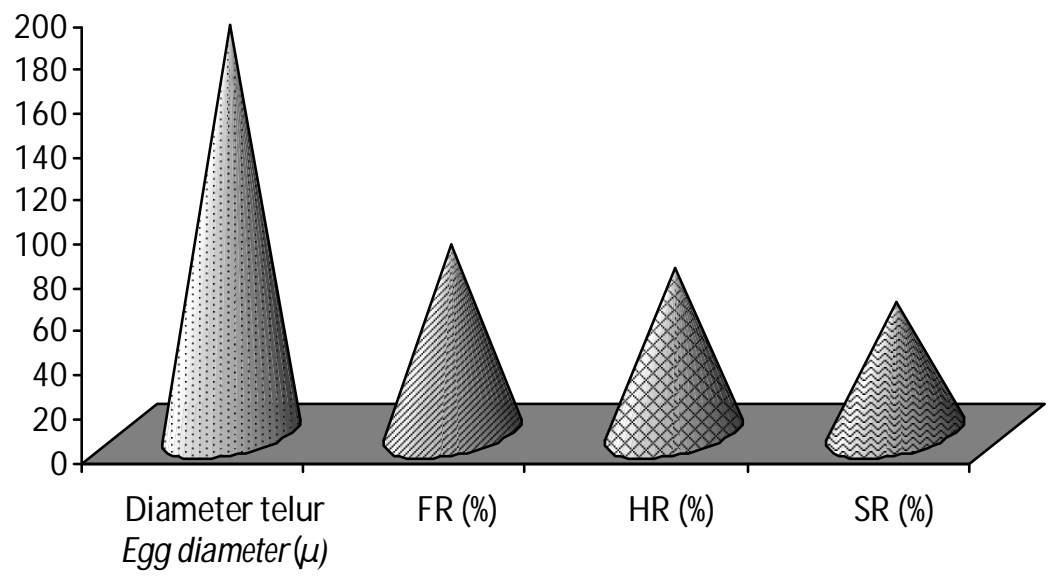

Gambar 4. Diameter telur, derajat pembuahan (FR), derajat penetasan (HR), dan sintasan (SR) abalon F-3.

Figure 4. Egg diameter, fertilization rate (FR), hatching rate (HR), and survival rate of $\mathrm{F} 3$ abalone. 


\section{KESIMPULAN}

Pertumbuhan abalon sangat dipengaruhi oleh ketersediaan pakan di plate terutama pada hari ke-50. Potensi reproduksi yang terlihat dari peningkatan proporsi jantan pada abalon F-3 menunjukkan terjadi ketidakseimbangan jumlah jantan dan betina sehingga perlu perhatian dalam proses seleksi. Abalon turunan ketiga pada umur 16 bulan mulai matang gonad dan dapat digunakan sebagai induk untuk pemijahan.

\section{UCAPAN TERIMA KASIH}

Penelitian ini dibiayai oleh DIPA BBPPBL-Gondol Bali TA. 2015. Penulis mengucapkan terimakasih kepada Bapak Hendra Agung, Sumarto, Arsyad, dan Ibu Siyam Sujarwani atas segala bantuan selama berlangsungnya penelitian ini.

\section{DAFTAR ACUAN}

Arai, K. \& Okumura, S.I. (2013). Aquaculture-oriented genetic researches in abalone: Current status and future perspective. African Journal of Biotechnology, 12(26), 4044-4052.

Apisawetakan, S., Thongkukiatkul, A., Wanichanon, C., Linthong, V., Kruatrachue, M., Upatham, E.S., Poomthong, T., \& Sobhon, P. (1997). The gametogenic processes in a tropical abalone, Haliotis asinina Linnaeus. J. Sci. Soc. Thailand, 23, 225-240.

Bilbao, A., Tuset, V., Viera, M., De Vicose, G.C., Hipólito, F.P., Haroun, R., \& Izquierdo, M. (2010). Reproduction, fecundity, and growth of abalone (Haliotis tuberculata coccinea, Reeve 1846) in the Canary Islands. Journal of Shellfish Research, 29(4), 959-967. 2010. DOI: 10.2983/035.029.0430.

Botsford, L.W., Castilla, J.C., \& Peterson, C.H. (1997). The management of fisheries and marine ecosystem. Science, 177, 509-515.

Botsford, L., Burton, R., Butler, J., Friedman, C., Gerber, L., Haaker, P., Kushner, D., Leighton, D., Cormick, M.T., Neuman, M., \& Bennet, L.R. (2006). Draft white abalone (Haliotis sorenseni) recovery plan. National Oceanic and Atmospheric Administration National Marine Fisheries Service Office of Protected Resource.

Daume, S. \& Ryan, S. (2004). Nursery culture of the abalone Haliotis laevigata: Iarval settlement and juvenile production using cultured algae or formulated feed. Journal of Shellfish Research, 23, 10191027.
Gjedrem, T. (2005). Selection and breeding program in aquaculture. Norway: Akvaforsk, As., 364 pp.

Jiaqi, L., Mingling, W., Jianguang, F., Xiao, L., Yuze, M., Guangmou L., \& Dapeng B. (2017). Reproductive performance of one-year-old Pacific abalone (Haliotis discus hannai) and its crossbreeding effect on offspring growth and survival. Aquaculture, 473, 110-114.

Onitsuka, T., Kawamura, T., Oaci, S., Horii, T., \& Wantabe, Y. (2004). Morphological changes in the radula of abalone Haliotis diversicolor aquatilis from past-larva to adult. Journal of Shellfish Research, 23, 1079-1086.

Permana, G.N., Rusdi, I., Susanto, B., Khotimah, F.H., \& Heri, S. (2013). Karakterisasi genetik hybrida abalon (Haliotis squamata dan Haliotis asinina). Prosiding Forum Inovasi Teknologi Akuakultur (FITA). Bidang Perakitan Strain dan Pemanfaatan induk unggul, kesehatan ikan, dan lingkungan. hlm. 533539. ISBN 978-979-786-046-9.

Permana, G.N., Rusdi, I., Susanto, B., Khotimah, F.H., $\&$ Haryanti (2015). Keragaan pertumbuhan dan variasi genetik abalon Haliotis squamata Reeve (1846) hasil seleksi F-1. Jurnal Riset Akuakultur, 10(3), 493-500.

Rusdi, I., Susanto, B., Rahmawati, R., Tirtayuda, H., \& Giri, I N.A. (2010). Perbaikan metode pemijahan induk dan pemeliharaan larva-juvenil abalon (Haliotis squamata) melalui pengelolaan lingkungan. Kumpulan makalah seminar hasil penelitian terbaik tahun 2009. Balitbang KP. Bogor, Tahun 2010. hlm. 12-32.

Rusdi, I., Susanto, B., Khotimah, F.H., \& Permana, G.N. (2015). Pertumbuhan dan sintasan yuwana abalon (Haliotis squamata) pada pendederan di bak dengan berbagai metode. Prosiding Forum Inovasi Teknologi Akuakultur. Pusat Penelitian dan Pengembangan Perikanan. hlm. 1081-1089.

Singhagraiwan, T. \& Doi, M. (1992). Spawning pattern and fecundity of the donkey's ear abalone, Haliotis asinina Linne. observed in captivity. Thai. Mar. Fish. Res. Bull., 3, 61-69.

Setyono, D.E.D. (2004). Conditioning broodstock of tropical abalone (Haliotis asinina) under different photoperiod. Oseanologi dan Limnologi di Indonesia, 36, 1-13.

Tave, D. (1993). Genetics for fish managers. NY, USA: The AVI Publ. Comp. Inc., 418 pp. 